\title{
Kinetic Characterization of Mitochondrial Malate Dehydrogenase from Dictyostelium discoideum
}

\author{
By RUTH G. EMYANITOFF*† AND PATRICK J. KELLY \\ Department of Developmental Biology, Boston Biomedical Research Institute, \\ 20 Staniford Street, Boston, Massachusetts 02114, U.S.A.
}

(Received 27 July 1981; revised 22 December 1981)

\begin{abstract}
Malate dehydrogenase (MDH; EC 1.1.1.37) from Dictyostelium discoideum was purified and characterized. MDH activity from whole cells was purified 275 -fold. The mitochondrial and cytoplasmic MDH present co-purified through three ion exchange and affinity chromatography steps. The isoenzymes were barely separable by either disc gel electrophoresis or isoelectric focusing. The purified preparation containing both isoenzymes had a single $\mathrm{pH}$ optimum (9.3-9.5) and an apparent molecular weight of 70000 . It exhibited linear kinetics and responded to known inhibitors of $\mathrm{MDH}$, i.e. thyroxine and hydroxymalonate. Michaelis and dissociation constants obtained with this preparation were similar to those obtained with a 10 -fold purified mitochondrial $\mathrm{MDH}$.
\end{abstract}

\section{INTRODUCTION}

Dictyostelium discoideum uses cellular protein as its source of tricarboxylic acid cycle intermediates during cell development (Wright, 1964). Kelly et al. (1979 b) developed a steady state model of the tricarboxylic acid cycle which is serving as a basis for development of a transition model of the cycle during differentiation (Wright, 1981). Malate dehydrogenase (MDH; EC 1.1.1.37) catalyses the reversible oxidation-reduction of malate and NAD to oxaloacetate and NADH. The intracellular concentration of oxaloacetate is the lowest of all the tricarboxylic acid cycle intermediates (Kelly et al., 1979a). Throughout differentiation it remains 2 - to 10 -fold lower than the next lowest pools (2-oxoglutarate and acetyl-CoA). $\mathrm{MDH}$ may play an important role in limiting the oxaloacetate concentration and, therefore, in controlling flux through the tricarboxylic acid cycle. In order to realistically evaluate the importance of this reaction in the kinetic model, the kinetic constants (Michaelis and dissociation constants) of MDH must be determined.

In mammalian systems MDH is present in the mitochondria, functioning in the tricarboxylic acid cycle, and in the cytoplasm, functioning in the 'malate shuttle' (Krebs et al., 1967). Our attempts to purify the mitochondrial enzyme from whole cell extracts of $D$. discoideum resulted in substantial purification of enzyme activity (275-fold) but failed to separate the mitochondrial and cytoplasmic enzymes. The enzyme was partially purified from isolated mitochondria to determine separately the kinetic constants of the mitochondrial enzyme.

\section{METHODS}

Enzyme assays. For enzyme purification and characterization, two fluorimetric assays were used. The assay for measuring oxaloacetate reduction contained $0.4 \mu \mathrm{mol} \mathrm{NADH} \mathrm{(Na} \mathrm{salt),} \mathrm{1.2 \mu mol} \mathrm{sodium} \mathrm{oxaloacetate,} \mathrm{and}$

† Offprint requests to Dr B. Wright. University of Montana, Missoula, Montana 59812, U.S.A.

‡ Present address: Academic Press, Inc.. New York, N.Y., U.S.A. 
sodium bicarbonate buffer $(100 \mu \mathrm{mol}, \mathrm{pH} \mathrm{9.5)}$ to a total of $2 \mathrm{ml}$. When measuring malate oxidation in the presence of NAD, hydrazine/glycine buffer (final concentration $0.4 \mathrm{M}$-hydrazine, $1 \mathrm{M}$-glycine, $\mathrm{pH} 9.5$ ) was used to remove the oxaloacetate as the hydrazone and allow the reaction to proceed against an equilibrium strongly favouring the opposite direction (Hohorst, 1965). The reactions were started by addition of enzyme, and NADH oxidation or NAD reduction was measured using a Perkin-Elmer fluorescence spectrophotometer. One unit of activity is defined as the amount catalysing the oxidation of $1 \mu \mathrm{mol} \mathrm{NADH} \min ^{-1}$ at $25^{\circ} \mathrm{C}$.

Enzyme purification from mitochondria. Dictyostelium discoideum NC4 (ATCC 24697) was grown with Escherichia coli on nutrient agar sheets (Marshall et al., 1970). Aggregation stage cells from 200 sheets (approximately $80 \mathrm{~g}$ dry wt) were harvested and washed three times in distilled water. They were subsequently suspended in $50 \mathrm{mM}$-Tris/ $\mathrm{HCl}$ buffer $(\mathrm{pH} 8 \cdot 0)$ containing $0.35 \mathrm{M}$-sucrose, $1 \mathrm{~mm}$-EDTA and $0.2 \%(\mathrm{w} / \mathrm{v})$ bovine serum albumin. Mitochondria were isolated according to the method of Komuniecki et al. (1980). The crude mitochondrial extract was prepared by resuspending the mitochondria in the same buffer without sucrose, freezing once, thawing, and centrifuging at $27000 \mathrm{~g}$ for $20 \mathrm{~min}$. This extract contained $0.25 \mathrm{~g}$ protein (assayed by the Lowry method using bovine serum albumin as a standard). The protein yield was low, partly because the mitochondrial isolation technique allowed only 10-15\% cell breakage. The mitochondrial extract had only one band of activity on a $7 \%$ polyacrylamide gel when stained for $\mathrm{MDH}$ activity (see below for details).

The crude extract was partially purified as follows. Streptomycin sulphate was added to a concentration of $1 \%$ $(\mathrm{w} / \mathrm{v})$. After the solution had been stirred for $45 \mathrm{~min}$ at $0^{\circ} \mathrm{C}$, the resulting precipitate was removed by centrifugation. The supernatant was taken to $60 \%$ saturation with $\left(\mathrm{NH}_{4}\right)_{2} \mathrm{SO}_{4}$ by slow addition of saturated $\left(\mathrm{NH}_{4}\right)_{2} \mathrm{SO}_{4}$. The precipitate was removed by centrifugation. Sufficient solid $\left(\mathrm{NH}_{4}\right)_{2} \mathrm{SO}_{4}$ was then added to bring the supernatant fluid to $90 \%$ saturation. The resulting precipitate was dissolved in $50 \mathrm{~mm}$-Tris/ $\mathrm{HCl}$ buffer (pH 8.0) containing $15 \%(\mathrm{v} / \mathrm{v})$ glycerol, $1 \mathrm{~mm}$-mercaptoethanol and $1 \mathrm{~mm}$-EDTA and dialysed overnight at $4{ }^{\circ} \mathrm{C}$ against the same buffer mixture. The dialysed protein solution was chromatographed on a column $(2 \times 20 \mathrm{~cm}) \mathrm{of}$ DEAE-Sephadex (Pharmacia) equilibrated with the same buffer. The MDH activity did not bind to the column. Fractions of $1 \mathrm{ml}$ were collected and those containing MDH activity were pooled.

Enzyme purification from whole cells. Pre-culmination stage cells from 50 sheets were harvested in $200 \mathrm{ml} 50$ $\mathrm{mm}$-Tris/ $\mathrm{HCl}$ buffer ( $\mathrm{pH} \mathrm{7.4).} \mathrm{The} \mathrm{suspension} \mathrm{was} \mathrm{frozen} \mathrm{and} \mathrm{thawed} \mathrm{three} \mathrm{times} \mathrm{and} \mathrm{then} \mathrm{centrifuged} \mathrm{at} 12000 \mathrm{~g}$ for $10 \mathrm{~min}$ to remove cell debris. Streptomycin sulphate was added to the supernatant to a final concentration of $1 \%(\mathrm{w} / \mathrm{v})$. After $45 \mathrm{~min}$ at $0^{\circ} \mathrm{C}$. the resulting precipitate was removed by centrifugation. The supernatant was taken to $60 \%$ saturation $\left(\mathrm{NH}_{4}\right)_{2} \mathrm{SO}_{4}$ by slow addition of saturated $\left(\mathrm{NH}_{4}\right)_{2} \mathrm{SO}_{4}(300 \mathrm{ml})$. The precipitate was removed, the supernatant was taken to $90 \%$ saturation with solid $\left(\mathrm{NH}_{4}\right)_{2} \mathrm{SO}_{4}(125 \mathrm{~g})$, and the resulting precipitate (60-90\% fraction) was removed. This fraction was dissolved in a standard buffer consisting of $50 \mathrm{~mm}-\mathrm{Tris} / \mathrm{HCl}$ (pH 7-4), $15 \%(\mathrm{v} / \mathrm{v})$ glycerol, $1 \mathrm{~mm}$-mercaptoethanol and $1 \mathrm{mm-EDTA}$, and dialysed overnight at $4{ }^{\circ} \mathrm{C}$ against the same buffer mixture. The non-diffusible fraction was then chromatographed on a column $(2 \times 20 \mathrm{~cm})$ of DEAE-Sephadex which had been equilibrated with standard buffer. The MDH activity did not bind to the column. Fractions containing MDH activity were combined and applied to a $2 \times 5 \mathrm{~cm}$ column of Sepharose-Blue (Pharmacia), an affinity material which adsorbs nucleotide-requiring enzymes (Thompson et al., 1975). The column was washed with $75 \mathrm{ml}$ of standard buffer. A linear gradient of NADH $(0-3.5 \mathrm{mM}$ in $200 \mathrm{ml}$ of standard buffer) was applied and $9.0 \mathrm{ml}$ fractions were collected and assayed. The activity eluted in fractions 6-13 and peaked at $1.3 \mathrm{~mm}-\mathrm{NADH}$. These fractions were pooled and dialysed overnight at $4{ }^{\circ} \mathrm{C}$ against standard buffer. The non-diffusible fraction was then chromatographed on a column $(2 \times 70 \mathrm{~cm})$ of Agarose A-1.5 (Bio-Rad) which had been equilibrated with standard buffer and $5.0 \mathrm{ml}$ fractions were collected and assayed. The activity eluted in fractions 33-39 as a symmetrical peak. Fractions containing activity were combined and concentrated using an Amicon model 8MC ultrafiltration system. Ultrafiltration, even in the presence of glycerol, resulted in loss of activity at this stage unless bovine serum albumin was included in the sample at a final concentration of about 1 $\mathrm{mg} \mathrm{ml}^{-1}$.

Electrophoresis. Disc gel electrophoresis was performed in acrylamide gels (7\% acrylamide, $0.2 \%$ bis-acrylamide) at $0-4{ }^{\circ} \mathrm{C}$ using a constant current of $2 \mathrm{~mA}$ per gel. The reservoir buffer was Tris/glycine (150 $\mathrm{mm}, \mathrm{pH} 8 \cdot 3$ ). After electrophoresis, the gels were removed from the gel tubes and placed in a foil-covered flask. To stain for enzymic activity, the gels were incubated with $20 \mathrm{ml}$ of a solution containing malate ( $30 \mathrm{~mm}$ ). NAD $(1.5 \mathrm{~mm})$, phenazine methosulphate $(0.3 \mathrm{~mm})$ and MTT tetrazolium $(2.5 \mathrm{~mm})$. After incubation (usually $20-30 \mathrm{~min})$ the stained bands were fixed in $7 \%(\mathrm{v} / \mathrm{v})$ acetic acid.

Isoelectric focusing. Gels ( $7 \%$ acrylamide. $0.2 \%$ bis-acrylamide) containing glycerol $(12 \%)$, ampholytes $(2 \%$, $\mathrm{pH}$ range $3-10)$ and riboflavin 5 '-phosphate $(10 \mathrm{~nm})$ were photopolymerized overnight. Samples for focusing

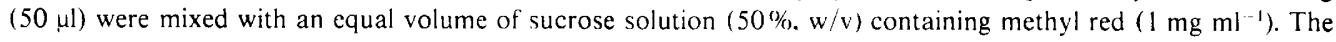
samples were applied to the gels and overlaid with sucrose $(10 \%)$ and $\mathrm{H}_{3} \mathrm{PO}_{4}(10 \mathrm{~mm})$ and the catholyte $\mathrm{NaOH}$ $(10 \mathrm{~mm})$. Runs were made at $0-4{ }^{\circ} \mathrm{C}$ at constant voltage $(300 \mathrm{~V})$ for at least $6 \mathrm{~h}$. After focusing. the gels were removed from their tubes, and the $\mathrm{pH}$ gradient established in the gels during focusing was determined with a surface electrode. Gels were then stained for activity or sectioned and assayed. 
Table 1. Purification of malate dehydrogenase from pre-culmination stage cells

\begin{tabular}{lcccccc}
\multicolumn{1}{c}{ Fraction } & $\begin{array}{c}\text { Volume } \\
(\mathrm{ml})\end{array}$ & $\begin{array}{c}\text { Protein } \\
\left(\mathrm{mg} \mathrm{ml}^{-1}\right)\end{array}$ & $\begin{array}{c}10^{-4} \times \text { Total } \\
\text { activity } \\
\text { (units) }\end{array}$ & $\begin{array}{c}\text { Specific activity } \\
\text { [units (mg protein) })^{-1} \text { ] }\end{array}$ & $\begin{array}{c}\text { Purification } \\
\text { factor }\end{array}$ & $\begin{array}{c}\text { Yield } \\
(\%)\end{array}$ \\
1. Crude extract & 210 & 31.8 & 1.40 & $2 \cdot 0$ & $(1)$ & $(100)$ \\
2. Strep. sulphate & 200 & 27.4 & $1 \cdot 20$ & $2 \cdot 2$ & $1 \cdot 1$ & 86 \\
3. (NH $)_{2} \mathrm{SO}_{4}(60-90 \%)$ & 62 & 14.9 & 0.58 & $6 \cdot 3$ & $3 \cdot 2$ & 40 \\
4. DEAE-Sephadex & 98 & 0.9 & 0.40 & $42 \cdot 8$ & $21 \cdot 4$ & 30 \\
5. Sepharose-Blue & 63 & 0.6 & 0.14 & 233 & 116 & 11 \\
6. Agarose A-1.5 & 32 & 0.2 & 0.11 & 550 & 275 & 8
\end{tabular}

\section{RESULTS AND DISCUSSION}

The MDH activity from mitochondria was purified 10 -fold, but only $1.6 \mathrm{mg}$ protein $(6.5 \%$ yield of MDH activity) remained, making further purification difficult. No NADH oxidase activity, which might interfere with the assay for $\mathrm{MDH}$, was detected. In contrast to the mitochondrial extract, purification of whole cell extracts by the same procedure resulted in a 21 -fold purification and a $30 \%$ yield (Table 1). Additional purification of MDH activity from whole cells was achieved by Sepharose-Blue affinity chromatography, Agarose A-1.5 chromatography, and concentration with an ultrafiltration system. This procedure resulted in a 275-fold purification of MDH activity ( $8 \%$ yield) containing both major MDH isoenzymes. There were two distinguishable but poorly resolved bands in both polyacrylamide disc gels and isoelectric focusing gels stained for enzymic activity. This behaviour differs from that of MDHs from other sources including chicken heart (Kitto \& Kaplan, 1966), Physarum polycephalum (Teague \& Henney, 1973) and Saccharomyces cerevisiae (Hagele et al., 1978). The mitochondrial and cytoplasmic enzymes from these sources were separable by affinity and ion exchange chromatography, separation being achieved because of differences in dinucleotide analogue affinity or charge differences between the isoenzymes (Banaszak \& Bradshaw, 1975). Evidently such differences are smaller between the MDH isoenzymes of $D$. discoideum.

The mitochondrial $\mathrm{MDH}$ activity was found to have a $\mathrm{pH}$ optimum of $9 \cdot 3-9.5$ using Tris $/ \mathrm{HCl}$ and bicarbonate buffers in assays over a $\mathrm{pH}$ range of $7-10$. This was much higher than the $\mathrm{pH}$ optimum $(6 \cdot 5-7 \cdot 5)$ reported from other sources (Flury et al., 1974; Kuan et al., 1979). Both thyroxine and hydroxymalonate inhibited the MDH activity. Thyroxine was 100 times more inhibitory $(50 \%$ inhibition at $0.06 \mathrm{mM})$ than hydroxymalonate $(50 \%$ inhibition at 6.0 mM). Inhibition by these compounds is characteristic of MDHs (Wolff \& Wolff, 1957).

Kinetic constants were determined using 10-fold purified mitochondrial MDH, and MDH from whole cells purified as far as the Sepharose-Blue step (116-fold). Initial velocity studies, with each substrate being used as the fixed or variable substrate, were done to determine Michaelis $\left(K_{\mathrm{m}}\right)$ and dissociation $\left(K_{\mathrm{i}}\right)$ constants. Lineweaver-Burk plots of the results of each set of experiments (e.g. a set of plots of reciprocal velocity versus reciprocal of NADH concentration for several fixed oxaloacetate concentrations) resulted in several families of straight lines. These, and re-plots of the $y$ intercepts of the lines versus the reciprocals of the fixed substrate concentrations gave the $K_{\mathrm{m}}$ and $K_{\mathrm{1}}$ values listed in Table 2 (Cleland, 1963). Malate concentrations used were $10 \cdot 0,5 \cdot 0,2 \cdot 0$ and $1.0 \mathrm{mM}$; NAD concentrations were $2 \cdot 0$, $1 \cdot 0,0.5,0.25$ and $0.1 \mathrm{~mm}$. Oxaloacetate concentrations used were $0 \cdot 25,0 \cdot 19,0 \cdot 125,0 \cdot 1$ and $0.06 \mathrm{~mm}$; NADH concentrations were $0.05,0.04,0.03,0.02$ and $0.01 \mathrm{~mm}$.

The whole cell MDH preparation, although containing two different isoenzymes, gave linear Lineweaver-Burk plots, and the values for $K_{\mathrm{m}}$ and $K_{\mathrm{i}}$ were similar to those for the mitochondrial MDH preparation (Table 2). The linearity of the reciprocal plots from initial velocity studies with MDH from whole cells suggested that it contained either (a) isoenzymes with very similar constants, or (b) isoenzymes with very different constants such that only the 
Table 2. Kinetic constants for MDH purified from whole cells and mitochondria

$\begin{array}{lcc}\text { Kinetic constant* } & \begin{array}{c}\text { Mitochondrial } \\ \text { MDH } \dagger \\ (\mathrm{mM})\end{array} & \begin{array}{c}\text { Whole cell } \\ \text { MDH } \\ (\mathrm{mM})\end{array} \\ K_{\mathrm{m}} \text { NADH } & 0.04 & 0.03 \\ K_{\mathrm{m}} \text { oxaloacetate } & 0.27 & 0.17 \\ K_{\text {iq }} \text { NADH } & 0.04 & 0.04 \\ K_{\mathrm{m}} \text { malate } & 1.33 & 5.0 \\ K_{\mathrm{m}} \text { NAD } & 0.10 & 0.14 \\ K_{\mathrm{ia}} \text { NAD } & 0.31 & 0.11\end{array}$

\footnotetext{
* Nomenclature of Cleland (1963).

+ Enzyme purified as far as DEAE-Sephadex chromatography step (10-fold).

‡Enzyme purified as far as Sepharose-Blue chromatography step (116-fold).
}

major isoenzyme was detected. It is probable that the presence of isoenzymes with kinetic constants differing by a factor of 2 or more would have resulted in non-linear reciprocal plots. The purified enzyme had a single $\mathrm{pH}$ optimum $(9 \cdot 3-9 \cdot 5)$. The apparent molecular weight of this $\mathrm{MDH}$, as determined by gel filtration on a calibrated Sephadex G-200 column $(1.5 \times$ $70 \mathrm{~cm}$ ), was 70000 . The activity chromatographed as a single symmetrical peak, and there was no evidence of heterogeneity. MDHs from a variety of eukaryotic sources all have similar molecular weights (Banaszak \& Bradshaw, 1975; Murphy et al., 1967).

Since the MDH purified from whole cells behaved as a homogeneous enzyme, and the kinetics of the mitochondrial and whole cell MDH preparations were comparable, the more highly purified whole cell MDH was used in product inhibition studies to obtain evidence regarding the enzyme kinetic mechanism. Plots were made of reciprocal velocity versus either oxaloacetate concentration or NADH concentration at a fixed unsaturated concentration of the second substrate, with either $0,0.025,0.050$ and 0.075 mM-NAD or $0,2.0,5.0$ and $10.0 \mathrm{mM}$-malate. The variable substrate concentrations were those used for determining kinetic constants (see above). The fixed NADH concentration was $0.5 \mathrm{~mm}$; the fixed oxaloacetate concentration was $1.25 \mathrm{~mm}$. In all cases the inhibition was found to be uncompetitive. This pattern of inhibition was consistent with an iso-ordered bi-bi reaction mechanism (Cleland, 1963). This mechanism has been determined by Heyde \& Ainsworth (1968) for bovine heart MDH and by Raval \& Wolfe (1962) for the porcine heart enzyme. Kinetic experiments are not sufficient to determine the order of substrate binding. However, an increase in fluorescence of the coenzyme was noted when enzyme was added in stoichiometric amounts. This indicated that NADH could combine with the free enzyme suggesting that the NADH/NAD pair were the first to bind to and the last to be freed from the enzyme (Heyde \& Ainsworth, 1968), which is generally thought to be the case for the dehydrogenases (Banaszak \& Bradshaw, 1975).

The authors are indebted to Dr B. E. Wright for her advice and encouragement. This investigation was supported by U.S. Public Health Service Grants AG00260 and AG00433 to Dr B. E. Wright from the U.S. National Institutes of Health.

\section{REFERENCES}

Banaszak, L. J. \& Bradshaw, R. A. (1975). Malate dehydrogenases. In The Enzymes, 3rd edn, vol. 11, pp. 369-396. Edited by P. D. Boyer. New York: Academic Press.

Cleland, W. W. (1963). The kinetics of enzymecatalyzed reactions with two or more substrates or products. Biochimica et biophysica acta 67, 104137.

Flury, V., Heer, B. \& Fiechter, A. (1974).
Regulatory and physiochemical properties of two isozymes of malate dehydrogenase from Schizosaccharomyces pombe. Biochimica et biophysica acta 341, 465-483.

Hagele, E., Neefe, J. \& Mecke, D. (1978). The malate dehydrogenase isozymes of Saccharomyces cerevisiae. European Journal of Biochemistry 83, 67-76.

Heyde, E. \& Ainsworth, S. (1968). Kinetic studies 
on the mechanism of the malate dehydrogenase reaction. Journal of Biological Chemistry 243. 2413-2423.

HoHORST, H. J. (1965). Determination of malate with malic dehydrogenase and DPN. In Methods of Enzymatic Analysis, 1st edn, pp. 328-332. Edited by H. U. Bergmeyer. New York: Academic Press.

Kelly, P. J., Kelleher. J. K. \& Wright, B. E. $(1979 a)$. Tricarboxylic acid cycle in Dictyostelium discoideum. Metabolite concentrations, oxygen uptake and ${ }^{14} \mathrm{C}$-labelled amino acid labelling patterns. Biochemical Journal 184, 581-588.

Kelly, P. J., Kelleher, J. K. \& Wright, B. E. $(1979 b)$. Tricarboxylic acid cycle in Dictyostelium discoideum. A model of the cycle at preculmination and aggregation. Biochemical Journal 184, 589597.

Kitto, G. B. \& Kaplan, N. O. (1966). Purification and properties of chicken heart mitochondrial and supernatant malic dehydrogenases. Biochemistry $\mathbf{5}$, 3966-3980.

Komuniecki, P. R., DeToma, F. J., Lawrence, M. H. \& DiDomenico, L. (1980). ADP phosphorylation and glutamate oxidation in mitochondria isolated from Dictyostelium discoideum amoebae. Biochemical and Biophysical Research Communications 96, 1017-1023.

Krebs, H. A., Gascoyne, J. \& Notton, B. N. (1967). Generation of extramitochondrial reducing power in gluconeogenesis. Biochemical Journal 102, 275282.

Kuan, K. N., Jones, G. L. \& Vestling, C. S. (1979). Rapid preparation of mitochondrial malate dehydro- genase from rat liver and heart. Biochemistry $\mathbf{1 8}$, 4366-4373.

Marshall, R., Sargent, D. \& Wright, B. E. (1970). Glycogen turnover in Dictyostelium discoideum. Biochemistry 9, 3087-3094.

Murphy, W. H., Kitto, G. B., Everse, J. \& KaPlan, N. O. (1967). Malate dehydrogenase. I. A survey of molecular size measured by gel filtration. Biochemistry 6, 603-610.

Raval, D. N. \& Wolfe, R. G. (1962). Malic dehydrogenase. II. Kinetic studies of the reaction mechanism. Biochemistry' 1, 263-269.

Teague, W. M. \& Henney, H. R., JR (1973). Purification and properties of cytoplasmic and mitochondrial malate dehydrogenases of Physarum polycephalum. Journal of Bacteriology 116, 673684.

Thompson, S. T., Cass, K. H. \& Stellwagen, E. (1975). Blue dextran sepharose: an affinity column for the dinucleotide folds in proteins. Proceedings of the National Academy of Sciences of the United States of America 72, 669-672.

WolfF, J. \& WolfF, E. C. (1957). The effect of thyroxine on isolated dehydrogenases. Biochimica et biophysica acta 26, 387-396.

Wright, B. E. (1964). Biochemistry of Acrasiales. In Biochemistry and Physiology of the Protozoa, vol. 3, pp. 341-381. Edited by S. H. Hutner. New York: Academic Press.

Wright, B. E. (1981). A transition model of the citric acid cycle in Dictyostelium. Abstracts of the Annual Meeting, American Society for Microbiology, abstract I144, p. 111. 